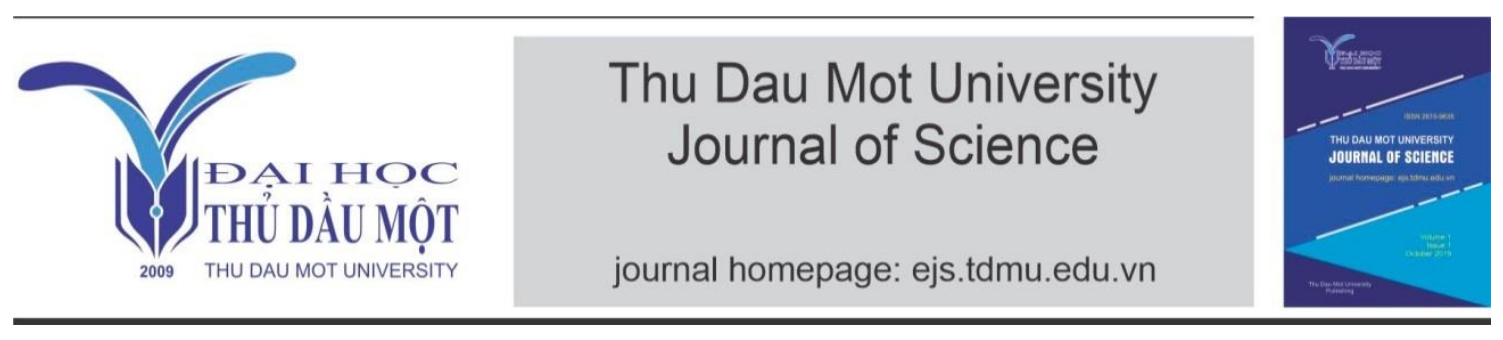

\title{
Investigating the impact of using language games on vocabulary teaching at a foreign language center in Binh Duong province
}

by Nguyễn Thành Thái (Thu Dau Mot University)

Article Info: $\quad$ Received 21 April 2021, Accepted 2 Sep 2021, Available online 15 Sep 2021

Corresponding author: thaint@tdmu.edu.vn

https://doi.org/10.37550/tdmu.EJS/2021.03.212

\begin{abstract}
The aim of this study was to explore the impact of using games in teaching vocabulary from the viewpoints of learners who already participated in language games. Through questionnaire, data for analysis were collected from 100 learners at a foreign language center in Binh Duong province. The results show that most of the participants are motivated to learn when they are in games. Moreover, they can acquire vocabulary more quickly and easily if the games are based on some factors such as learners' gender, age and education status. The study suggests that in spite of the effectiveness of using games in vocabulary teaching, games should not be used too much or too less in the classrooms.
\end{abstract}

Keywords: teaching, learning, language games, vocabulary, motivator

\section{Introduction}

Along with the socio-economic development, English has become an international language and now is the first foreign language which is officially taught in Viet Nam. However, it is not easy to teach English to all learners because it is new and not our mother tongue. The difficulties that learners may encounter are the lack of motivation to learn English since they are not exposed to hear and practice English everywhere and all the time. Therefore, teachers should have good and interesting techniques to make them feel more motivated to learn English. Using games is one of the best ways to introduce 
English to learners.

Using games in English teaching has gained much attention in recent years, because a proper learning atmosphere has not been ensured in English classes according to learners' interests and psychological characteristics. In order to appeal to learners' learning styles, games can be very effective tools for teaching a foreign language. Although some teachers of English see language games as time consumers or activities for fun, language games have a special role in any foreign language program because they facilitate foreign language learning (Gulin Yolagelidi \& Arda Arikan, 2011). Therefore, this study focuses on the impact of using games in teaching English vocabulary at a foreign language center in Binh Duong province.

\section{Literature Review}

\subsection{What are language games?}

According to The Longman Dictionary of Language Teaching and Applied Linguistics (Richarchs, Platt, \& Platt, 1995), games are defined as "an organized activity that usually has the following properties: a particular task or objective, a set of rules, competition between players, and communication between players by spoken or written language" (p.89). It can be a form of physical or mental activities or a mixture of the two.

With regard to linguistic aspect, language games are games related to language, teachers use them as techniques to motivate students and develop their language skill. When playing these language games, leaners not only have fun but also can practice English enjoyably. Greenall (1984) defines language game as one kind of "activity which is used to consolidate the taught and acquired language and occurs during the free stage of lesson or during occasions such as English club meeting..." However, they are not activities mainly aiming to break the ice between learners or to kill time. As Greenall (1984) gave the definition "They are not just a diversion, a break from routine activities, but a way of getting the learner to the use the language in the course of the game". The main focus of using game in class is to help student learn and have fun. When using games in the classroom, it is important that teacher should clearly explain the rules of game. Demonstrations also can be very helpful because it can help students understand the game and help them follow the rules (Deesri, 2002). Moreover, according to Khine (2011), when games are integrated in the lessons, teachers need to be aware of pedagogical aspects depending on the nature of the subject and characteristics of the students. As different students learn and progress information on their own ways, it is important to understand individuals' learning style which allow predicting how learners will react and feel in gaming situation. We need to consider the age level, gender, 
number of players and the role of the teacher to select appropriate genre of games.

\subsection{Types of language games}

According to "Investigating the Impact of Using Games in Teaching Children English" (Ying-Jian Wang, Hui-Fang Shang, \& Paul Briody, 2011), there are many types of games that can be employed in a contemporary EFL learning environment. It is difficult to classify games into categories because such categories often overlap. Therefore, different experts use different ways to classify language games. Hadfiled (1987) states that "language games can be divided into two further categories: linguistic games and communicative games. The former focus on accuracy, such as applying the correct antonym while the latter focus on successful exchange of information and ideas, such as two people identifying the differences between their two pictures which are similar to one another but not exactly alike". He also classifies language games into many more categories as follows:

- Sorting, ordering or arranging games. For example, students have a set of cards with different products of them, and they sort the cards into products found at a grocery store and products found at a department store.

- Information gap game: In such games, one student has access to the information which is not held by the other student, and this student must acquire the information to complete the task successfully. Information gap games can involve a one-way information gap or a two way information gap.

- Guessing games: In these games, someone knows something and the others must find out what it is

- Matching games: As a name applies, participants need to find a match for a word, picture or card.

- Labeling games: These are form of matching, in that participants match labels and pictures

- Puzzle-solving games: The participants in the game share or pool information in order to solve a problem or a mystery.

- Role play games: The terms role play, drama and simulation are sometimes used interchangeably but can be differentiated. Role play can involve students playing roles that they do not play in real life, such as dentists, while simulations can involve students performing roles that they already play in real life or might be likely to play, such as a customer at a restaurant. Dramas are normally scripted performances, whereas in role plays and simulations, students come up with their own words, although preparation is often useful.

\subsection{Opinion on using games in teaching English vocabulary}


Games provide many advantages when they are used in classroom. One of these advantages is that learners are motivated to learn a language. Learners enjoy games and thus participate without anxiety. Games can motivate learners greatly (Sophie loannouGeorgiou, 2010). Deesri (2002) further states that games spur motivation and students get very absorbed in the competitive aspects of games. Moreover, they try harder at games than in other courses. Reuben (1999) shares the same viewpoint that using games in class encourages active learning, as well as collaboration, and interactivity. In other words, games stimulate students' interest in classroom activities, so they become motivated and willing to learn. Therefore, learners can acquire vocabulary more quickly and easily by doing actions during game playing (Wang, Ying-Jian; Briody, Hui-Fang Shang \& Paul, 2011). By using a game which offers learners lots of opportunities to play and practice in class, learners can acquire a greater quantity of meaningful vocabulary. "During enactments, classmates interact in their role playing, thus enabling students to acquire additional vocabulary, often unconsciously" (Larsen-Freeman, 2001). Furthermore, games, which are designed for learners who have bodily intelligence or so-called kinesthetic intelligence, can help students memorize and utilize new vocabulary more efficiently (Richards \& Rodgers, 2001). Also, Atake (2003) made the following statement in her research, arguing that "students are challenged to think and use certain target vocabulary expressions but in games it becomes easier for students to memorize because students are impressed by competing or interacting with classmates" (p. 13). Another advantage associated with games is that children can understand and remember vocabularies in some topics easier through games. Some studies show that "learning through play" provides a successful education experience. Through fun activities, young learners can learn a language better as learning becomes natural for them since these activities do not make them conscious that they are learning a language (Ara, 2009). Also, Uberman (1998) also says that "after learning and practicing new vocabulary, students have the opportunity to use language in a nonstressful way." Through well-planned games, leaners can put into practice and internalize vocabulary, grammar and structures extensively (Slawek, 2007). As a result, they can lower anxiety and can use the target language better.

In contrast, some experts said that using games in English teaching is time consumer since they are just a technique for fun. In addition, they are not productive due to the generation of anxiety which makes children nervous and even depressed, because they are afraid of losing games or being blamed by partners for their performance. For instance, in accordance with the result that Wu (2004) conducted in his research, competitiveness in games is one of the major resources of language anxiety. They are afraid of being scolded by their peers; consequently, answering correctly becomes party to a stressful environment. Chuang (2007) also shares the same idea that children's 
anxiety increases because they are afraid of being blamed by their team members. From these authors, playing games can increase children's anxiety largely as the result of peer pressure.

To sum up, the use of language games is still a controversy issue which many experts have not figured out for years. However, it cannot be denied that games have a great pedagogical value providing language teachers with many benefits when they are used in classroom. The review of this study related to language games indicates that games are important in teaching English vocabulary. In order to get a clearer picture of how language games impact on teaching vocabulary, I conduct a survey which investigates how language games impact on teaching vocabulary. To reach this goal, the research questions are raised as follows:

1. How useful are language games as learning activities in English lessons?

2. To what extent do language games motivate students to learn vocabulary?

3. How often should teachers use games in classes?

\section{Methodology}

\subsection{Study design}

In this study, the researcher conducted a survey on learners' perceptions of the use of language games in vocabulary teaching and learning. It is important to choose a suitable and reliable method to conduct the research. After considering some factors relating to the research, survey questionnaire is seen as an effective way.

\subsection{Participants}

A total of 100 learners, 44 women (44\%) and 56 men (56\%) who are learning English at a foreign language center in Binh Duong province, participated in this study. More importantly, $75 \%$ of the participants were in the ages between 6 and 25, and only $25 \%$ were over 25 (see Table 1). Table 2 also shows that the participants differed significantly on current education status. $60 \%$ of the participants were primary and high school students, $20 \%$ of them were university students, and others are university graduates.

TABLE 1. Participants' age

\begin{tabular}{ccc}
\hline Age band & No. & $\%$ \\
\hline $6-10$ & 30 & 30.0 \\
$11-17$ & 30 & 30.0 \\
$18-25$ & 15 & 15.0 \\
Over 25 & 25 & 25.0 \\
\hline Total & 100 & 100.0 \\
\hline
\end{tabular}

TABLE 2. Participants' education status

\begin{tabular}{lcc}
\hline & No. & $\%$ \\
\hline Primary student & 30 & 30.0 \\
\hline High school student & 30 & 30.0 \\
\hline University student & 20 & 20.0 \\
\hline University graduate & 20 & 20.0 \\
\hline Total & 100 & $100 . C$ \\
\hline
\end{tabular}




\subsection{Data collection instrument and procedure}

In this study, the instrument used to elicit and collect information was in the form of questionnaire. The questionnaire, composed of twelve Likert-type items, was divided into two sections. The first section contained three questions to gain the participants' personal information on gender, age, and current education status. The second section dealt with the participants' perceptions of the use of language games in vocabulary teaching and learning. In this section, the participants would be asked to answer each question including a statement or question followed by responses.

It took 7 days to collect data from the participants. The long period time ensures that the respondents take the questionnaire into consideration so as to give their thoughtful answers. The questionnaire (Vietnamese version) was administrated after the class time. Before the questionnaire was given to them, I took time to explain the purpose of the questionnaire and the participants were also encouraged to raise any questions if there was anything unclear in the survey questionnaire. Then they were instructed to complete the questionnaire.

\subsection{Procedure of data analysis}

Altogether 100 questionnaires were collected back, and none of them were considered invalid. The data collected from the questionnaires was processed and analyzed by a statistical software SPSS (Statistical Package for the Social Sciences) version 16. Descriptive statistics, such as the mean, SD (standard deviation), the range, variance, maximum and minimum values, etc., which are generated by using descriptive analysis method of SPSS software, provide a convenient way of summarizing and interpreting data results. Therefore, the researchers used descriptive analysis for organizing and summarizing of the participants' questionnaire data of this study.

Data were processed through three main steps. First, for data analysis, I implemented the coding of the questionnaire. Second, the answers from the questionnaires were inputted into the statistical software (SPSS). The answers (ticked boxes) were scored on the basis of the participants' response to each question. For each question, I counted how many participants had answered with the same point. The average scores and standard deviations of all questions were also calculated. Finally, I displayed the data results in the form of descriptive statistics (tables, charts, etc.). In this stage, the results of the survey became more visual and quantitative for discussion, analysis and report.

\section{Findings and Discussions}

The findings obtained from the survey are discussed elaborately in this part of the paper. For the evaluation of the participants' perceptions of the use of language games in 
vocabulary teaching and learning, the responses to the questionnaire are shown by descriptive statistics in table 3 which describes the items by minimum, maximum and mean values and SD.

TABLE 3. Students' perceptions of the use of language games in vocabulary teaching and learning

\begin{tabular}{|c|c|c|c|c|c|}
\hline Questionnaire items & $\mathrm{N}$ & Min & Max & Mean & Std. Deviation \\
\hline Do you play language games in your class? & 100 & 1.00 & 3.00 & 1.54 & .70238 \\
\hline $\begin{array}{l}\text { Do you like language games given by your } \\
\text { teacher during the lessons? }\end{array}$ & 100 & 1.00 & 4.00 & 2.40 & 1.13707 \\
\hline $\begin{array}{l}\text { Are you willing to take part in during the } \\
\text { lessons? }\end{array}$ & 100 & 1.00 & 3.00 & 1.76 & .68343 \\
\hline How do you feel after playing games? & 100 & 1.00 & 4.00 & 2.28 & .99575 \\
\hline $\begin{array}{l}\text { Playing language games helps you learn } \\
\text { and remember words easily. }\end{array}$ & 100 & 1.00 & 2.00 & 1.42 & .49604 \\
\hline $\begin{array}{l}\text { Do you encounter any difficulties while } \\
\text { playing language games? }\end{array}$ & 100 & 1.00 & 3.00 & 2.07 & .72829 \\
\hline $\begin{array}{l}\text { Q10. How often do you want to play language } \\
\text { games? }\end{array}$ & 100 & 1.00 & 4.00 & 1.92 & .97110 \\
\hline $\begin{array}{l}\text { Q11. What is the perfect time to use a game in an } \\
\text { English class? }\end{array}$ & 100 & 1.00 & 4.00 & 2.59 & 1.01598 \\
\hline Q12. What type of grouping do you prefer? & 100 & 1.00 & 3.00 & 2.11 & .76403 \\
\hline
\end{tabular}

However, in order to arrive at a clear understanding of how language games impact on vocabulary teaching and learning, the analysis of each question is needed.

TABLE 4. The use of language games in classes

\begin{tabular}{ccc}
\hline Do you play language games in your class? & Frequency $(\mathrm{N}=100)$ & Percent $(\%)$ \\
\hline Yes & 58 & 58.0 \\
No & 30 & 30.0 \\
Rarely & 12 & 12.0 \\
\hline
\end{tabular}

Using games in class encourages active learning (Reuben, 1999) and helps learners acquire vocabulary more quickly and easily by doing actions during game (Wang, et al, 2011). Therefore, with regard to the use of language games in class (Q4), findings from the survey (see table 4) show that the great majority of the participants played language games in their classes. Only $30 \%$ did not. It implies that language games become increasingly popular and are exploited by most of the teachers.

TABLE 5. Students' attitudes towards language games

\begin{tabular}{lcc}
\hline $\begin{array}{l}\text { Do you like language games given by your teacher during the } \\
\text { lessons? }\end{array}$ & Frequency (N=100) & Percent (\%) \\
\hline I like them very much & 29 & 29.0 \\
Yes, they are OK & 25 & 25.0 \\
I don't like them at all & 23 & 23.0 \\
\hline
\end{tabular}


TABLE 6. Q5's result of one-sample t-test

\begin{tabular}{ccccccc}
\hline & \multicolumn{6}{c}{ Test Value $=2$} \\
\cline { 6 - 7 } & \multirow{2}{*}{$\mathrm{t}$} & df & \multirow{2}{*}{ Sig. (2-tailed) } & Mean & 95\% Confidence Interval of the Difference \\
\cline { 5 - 7 } & & & & Difference & Lower & Upper \\
\hline Q5 & 3.518 & 99 & .001 & .40000 & .1744 & .6256 \\
\hline
\end{tabular}

With regard to learners' attitudes towards language games (Q5), Table 5 displays that the majority of the participants (29\% and $25 \%$ ) prefer language games while up to $23 \%$ of the participants do not like language games and the other $23 \%$ of the participants had no idea. Also, Table 3 shows that the average score of all participants' responses to this question ( $\mathrm{M}=2.40)$ was a little over 2.0 which is the point of "Yes, they are OK". A onesample t-test was conducted to evaluate whether the mean of Q5 was significantly different from 2.0. The result (see Table 6) shows that the sample mean $\mathrm{M}=2.40$ $(\mathrm{SD}=1.134)$ was a little different from $2.0(\mathrm{t}=3.518, \mathrm{df}=99, \mathrm{p}=.001)$. The $95 \%$ of confidence internal of difference ranged from 2.0 to 2.4. The result supports the conclusion that the mean of participants' attitudes towards language games was higher than 2.0. This implies that a large number of learners have positive attitude towards language games, so it can be effective if teachers use them appropriately.

TABLE 7. Students' participation in lessons

\begin{tabular}{lcc}
\hline Are you willing to take part in during the lessons? & Frequency & $(\%)$ \\
\hline Yes, I feel more interested and motivated & 38 & 38.0 \\
It depends on the given activities and the language games & 48 & 48.0 \\
No, I feel unmotivated & 14 & 14.0 \\
\hline
\end{tabular}

$T A B L E$ 8. Means between learners' age and willingness to participate in games

Q6. Are you willing to take part in during the lessons?

\begin{tabular}{cccc} 
Age & Mean & $\mathrm{N}$ & Std. Deviation \\
$6-10$ & 1.3667 & 30 & .49013 \\
$11-17$ & 1.5000 & 30 & .57235 \\
$18-25$ & 2.2000 & 15 & .67612 \\
Over 25 & 2.2800 & 25 & .54160 \\
Total & 1.7600 & 100 & .68343 \\
\hline
\end{tabular}

According to Table 7, up to $38 \%$ of the participants feel more interested and motivated to take part in during the lesson while $48 \%$ prefer taking part in the lessons depending on the given activities and the given language games. Despite this, only $14 \%$ of the participants are unmotivated to participate in language games. Furthermore, according to Figure 1, learners' willingness to take part in language games varies according to age. With regard to learners with the age between 6 and 10,63.3\% of them were willing to 
participate in games, while $64 \%$ of learners over 25 usually consider the given language games before participating in them. Meanwhile, the result of comparing means between learner's age and willingness to participate in games (see Table 8) shows that the older the learners are, the less willing they are to participate in.

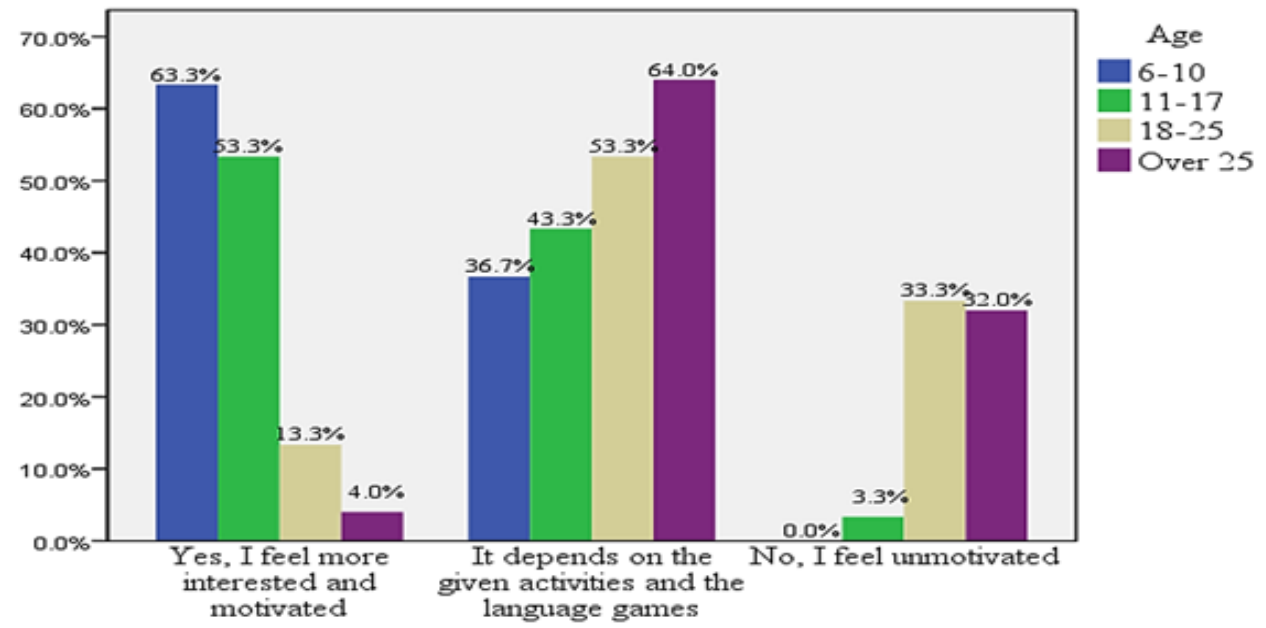

Figure 1. Students' participation in lessons according to age

TABLE 9. Students' feelings towards language games exploited by the teacher

\begin{tabular}{ccc}
\hline How do you feel after playing games? & Frequency $(\mathrm{N}=100)$ & Percent $(\%)$ \\
\hline Relaxed and motivated & 27 & 27.0 \\
Normal & 30 & 30.0 \\
Uncomfortable & 31 & 31.0 \\
Bored & 12 & 12.0 \\
\hline
\end{tabular}

TABLE 10. Comparing means between learner's education status and feelings towards language games

\begin{tabular}{l|lccc}
\hline \multirow{4}{*}{$\begin{array}{l}\text { Q7. How do you } \\
\text { feel after playing }\end{array}$} & Participants & Mean & $\mathrm{N}$ & Std. Deviation \\
\cline { 2 - 5 } games? & Primary student & 1.60 & 30 & .67466 \\
& High school student & 2.30 & 30 & 1.05536 \\
& University student & 2.50 & 20 & .94591 \\
& University graduate & 3.05 & 20 & .68633 \\
\cline { 2 - 5 } & Total & 2.28 & 100 & .99575 \\
\hline
\end{tabular}

This question deals with how students feel after playing games. The results from Table 9 shows that $27 \%$ of the participants felt relaxed and motivated after participating in language games, $30 \%$ felt normal, $31 \%$ felt uncomfortable and $12 \%$ felt bored. The mean ( $M=2.28)$ of this question was a little over the point 2.0. The result of one-sample $\mathrm{t}$-test shows that the mean $\mathrm{M}=2.28(\mathrm{SD}=1.134)$ was a little different from $2.0(\mathrm{t}=2.812$, $\mathrm{df}=99, \mathrm{p}=.005$ ). The $95 \%$ of confidence internal of difference ranged from 2.00 to 2.28 . The result supports the conclusion that the mean of participants' feelings towards language games was higher than 2.0. It indicates that a large number of students enjoy 
playing games. This positive attitude reassures the feasibility of using language games as a motivator in classes.

Furthermore, Figure 2 shows that up to $70 \%$ university graduates and 35\% university students felt uncomfortable after playing game while up to 50\% primary students feel relaxed and motivated. Meanwhile, the result of comparing means between learner's education status and feelings towards language games (see Table 10) shows that the higher education status the learners are in, the more uncomfortable and bored they feel when they are in game. These come to conclusion that the use of language games is feasible in teaching vocabulary to children and become more and more difficult to those who have higher education status.

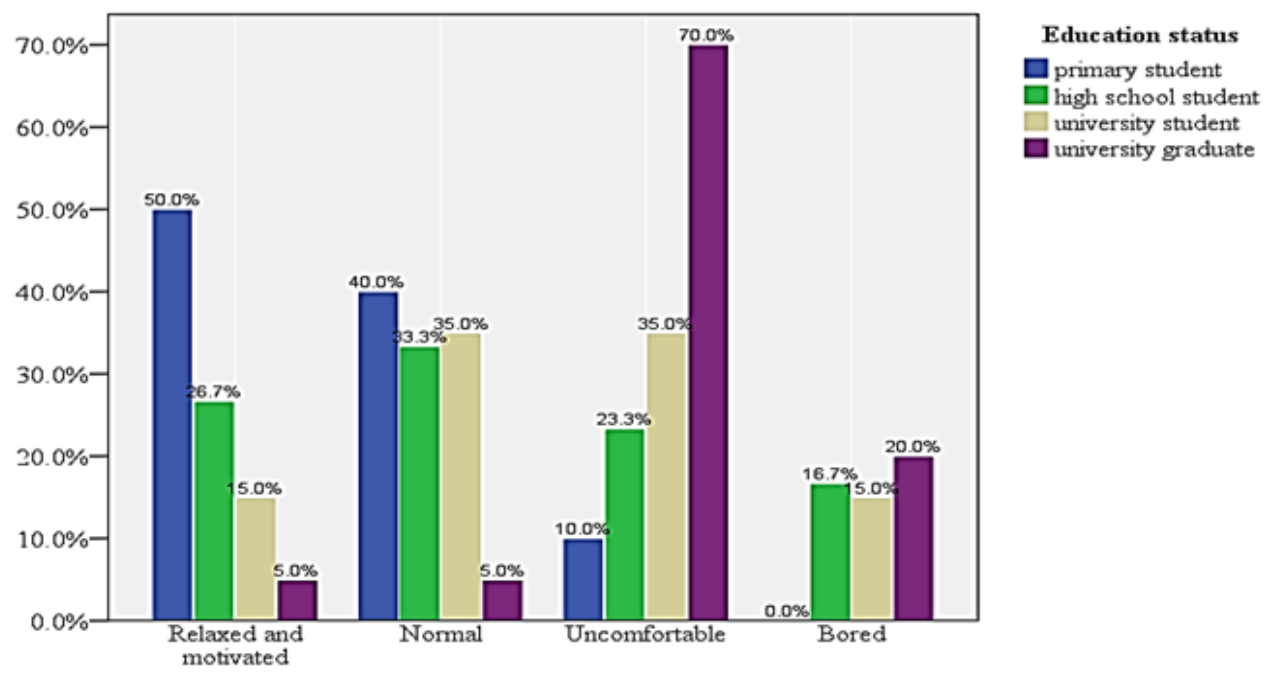

Figure 2. Students' feelings towards language games classified according to education status

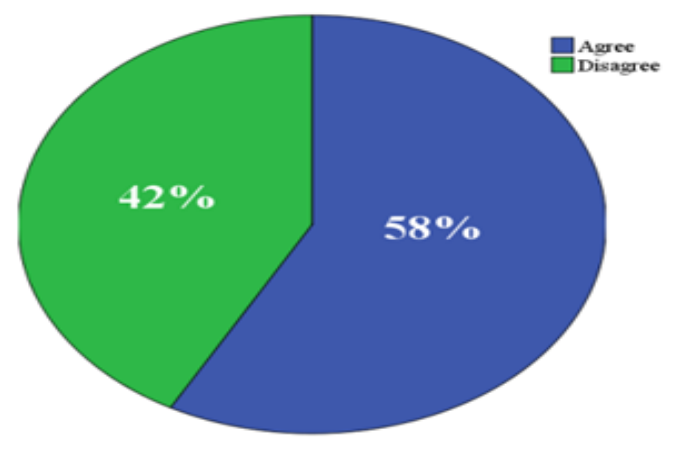

Figure 3. Benefits of using language games in classes

Figure 3 illustrates that most of the participants (58\%) agreed that games help them discover and memorize words easily while $42 \%$ of the participants disagreed. It indicates that games are not only enjoyable and fun but also help learners acquire the target language better. 
TABLE 11. Students' difficulties in language games

\begin{tabular}{lccc}
\hline $\begin{array}{l}\text { Do you encounter any difficulties while playing language } \\
\text { games? }\end{array}$ & Frequency (N=100) & Percent (\%) \\
\hline Yes & 23 & 23.0 \\
No & 47 & 47.0 \\
Rarely & 30 & 30.0 \\
\hline
\end{tabular}

Table 11 shows that $23 \%$ of participants stated that sometimes they encounter difficulties while playing language games, while $47 \%$ of the participants stated that they did not face any difficulties and $30 \%$ of the participants stated that they were rarely in trouble. This indicates that although most of the learners enjoy playing games, they still face with some problems while participating in them.

TABLE 12. The frequency of joining in language games

\begin{tabular}{ccc}
\hline How often do you want to play language games? & Frequency $(\mathrm{N}=100)$ & Percent $(\%)$ \\
\hline Often & 42 & 42.0 \\
Occasionally & 33 & 33.0 \\
Rarely & 16 & 16.0 \\
Never & 9 & 9.0 \\
\hline
\end{tabular}

Table 12 shows that $33 \%$ of participants prefer playing language games occasionally, $42 \%$ like playing games frequently while $16 \%$ rarely want to take part in language games. There were only $9 \%$ of the participants who never want to join in games. The mean $(\mathrm{M}=1.92)$ of this question was nearly equal to the point 2.0 which is the accepted mean for "playing language games occasionally". This indicates that the students prefer learning and playing at the same time. They do not want to play games too much or too less. It implies games should not be overused to avoid boredom and ineffectiveness.

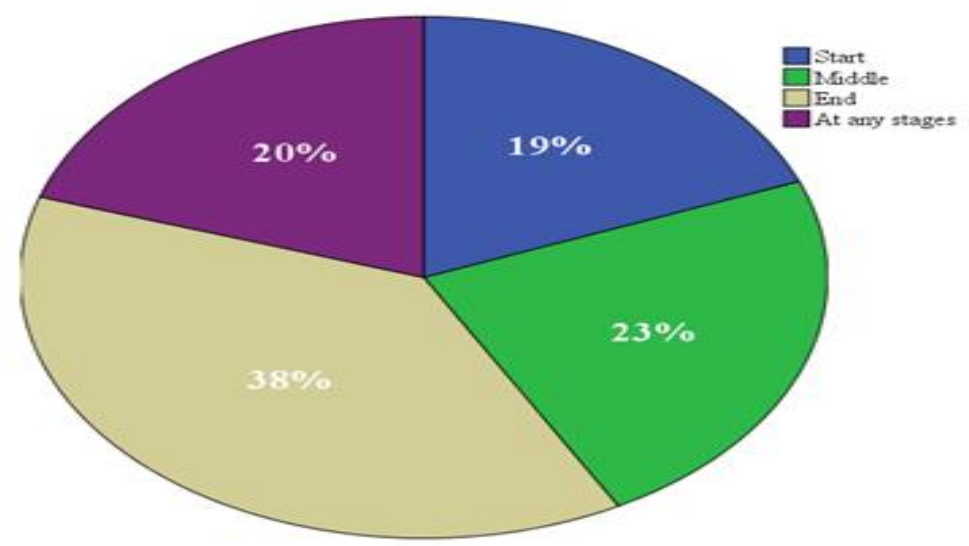

Figure 4. When to use language games

Figure 4 shows that $20 \%$ of the participants stated that language games can be used at any stages, 19\% admitted that games can be effective when using in the beginning of the lesson, 23\% agreed that games should be used in the middle of the lesson, and the other 
$38 \%$ of the participants believed that the use of language games at the end of the lesson is the best.

TABLE 13. Type of grouping

\begin{tabular}{ccc}
\hline What type of grouping do you prefer? & Frequency $(\mathrm{N}=100)$ & Percent $(\%)$ \\
\hline Individual & 24 & 24.0 \\
Pair work & 41 & 41.0 \\
Group work & 35 & 35.0 \\
\hline
\end{tabular}

TABLE 14. Independent sample t-test between gender and the preference of grouping

\begin{tabular}{llcccc}
\hline \multicolumn{5}{c}{ Group Statistics } \\
\hline \multirow{4}{*}{ Q12 } & Gender & $\mathrm{N}$ & Mean & Std. Deviation & Std. Error Mean \\
& Male & 56 & 2.1071 & .80178 & .10714 \\
& Female & 44 & 2.1136 & .72227 & .10889 \\
\hline
\end{tabular}

Independent Sample Test

\begin{tabular}{|c|c|c|c|c|c|c|c|c|c|}
\hline & \multicolumn{4}{|c|}{$\begin{array}{c}\text { Levene's Test for } \\
\text { Equality of } \\
\text { Variances }\end{array}$} & \multicolumn{5}{|c|}{ t-test for Equality of Means } \\
\hline & \multirow[t]{2}{*}{$\mathrm{F}$} & \multirow[t]{2}{*}{ Sig. } & \multirow[t]{2}{*}{$\mathrm{t}$} & \multirow[t]{2}{*}{ df } & \multirow[t]{2}{*}{$\begin{array}{l}\text { Sig. (2- } \\
\text { tailed) }\end{array}$} & \multirow{2}{*}{$\begin{array}{c}\text { Mean } \\
\text { Differen } \\
\text { ce }\end{array}$} & \multirow{2}{*}{$\begin{array}{c}\text { Std. } \\
\text { Error } \\
\text { Differenc } \\
\text { e }\end{array}$} & \multicolumn{2}{|c|}{$\begin{array}{l}\text { 95\% Confidence } \\
\text { Interval of the } \\
\text { Difference }\end{array}$} \\
\hline & & & & & & & & Lower & Upper \\
${$\hline \multirow{2}{*}\text{Q12}{}${ \hline \multirow { 2 } { * } \text { Q12 } \begin{array} { c } { \begin{array} { c } { \text { Equal } } \\
{ \text { variances } } \\
{ \text { assumed } } \end{array} } \\
{ } \begin{array} { c } { \text { variances not } } \\
{ \text { assumed } } \end{array} }$ \\
\end{tabular}$} &{1.441} &{.233} &{-.042} &{98} &{.967} &{-.00649} &{.15470} &{-.31349} &{.30050} \\
{\hline} &{ } &{ } &{-.043} &{96.126} &{.966} &{-.00649} &{.15276} &{-.30972} &{.29673} \\
$\hline$\end{array}$

Table 13 shows that $35 \%$ of the participants prefer group work while up to $41 \%$ of the participants prefer pair work. Only $24 \%$ of the participants have worked individually. An independent-sample t-test was conducted to evaluate whether male and female are different in terms of grouping. Table 14 illustrates the results obtained from two different groups (males and females). The results indicate that there is not a difference between male and female in terms of grouping $(p=0.967)$, in which the mean for female is 2.10 while that for male is 2.1 .

Moreover, Figure 5 shows that about $27 \%$ of the male participants prefer individual work and about $38 \%$ prefer group work, while about a half of all the female participants $(47.7 \%)$ prefer pair work. This implicates that for language games to work effectively, teachers should take consideration of learners' gender. For example, if the quantity of female students in class is higher than male ones, teachers should design more activities 
in pair. And, if the quantity of male students in class is higher than female ones, teachers should design more activities in group.

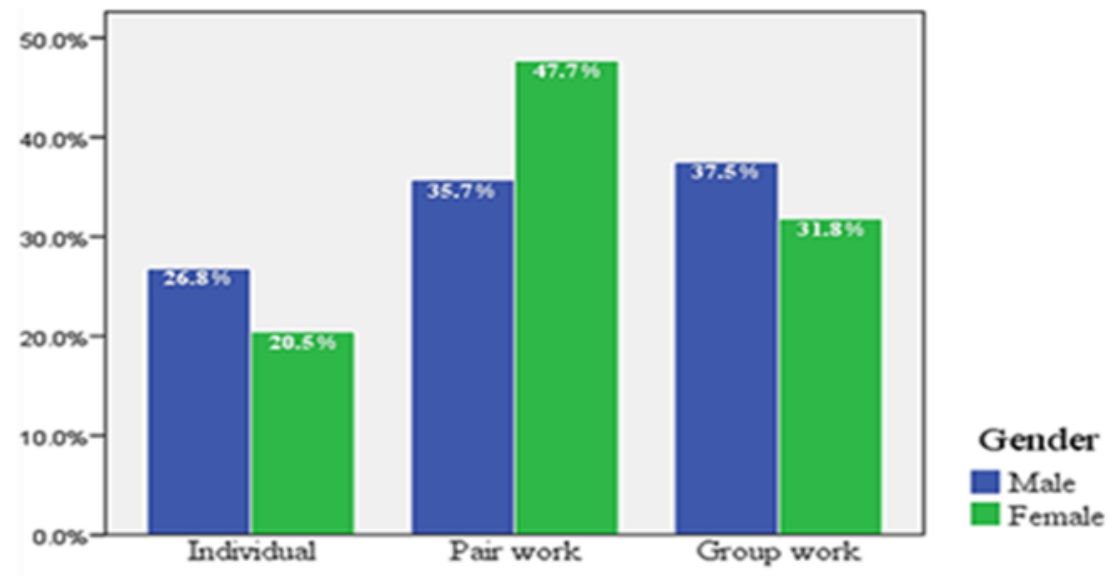

Figure 5. Type of grouping according to gender

\section{Conclusions and Recommendations}

Basically, findings show that language games can be exploited as a motivator for young learners rather than elder learners in vocabulary learning since it can arouse the interest in learning among the majority of young learners. Arikan (2011) express that games are one of the best way to direct young learners' energy into language learning because young leraners like to be physical active. Moreover, they are imaginative and creative and they learn subconciously. Therefore, using language game in teaching vocabulary requires a special effort and challenge by teachers because teachers are required to take consideration of learners' gender, age and education status in designing activities by games. It also creates a good classroom dynamics and enables students to refesh their minds. "It is a great tool for all levels, though it may serve different purposes and may be used in different ways" (Palanova, 2010). For all those reasons, it is advisible for teachers to take advantages of games, giving students the opportunity to ultilize its benefits. However, several factors would need to be considered in the design of a game, and in the design of its assessment. Teachers would need to give clear instruction and assessment, and carefully consider how learners can demonstrate what they may have gained from the activity. Teachers also need to consider how much and when it is appropriate to use games in the language teaching in order to be beneficial to the students and the whole teaching process. With the improved design and applications, teachers will discover effective ways to integrate the games in their teaching. It is hope that this paper will serve as a resource for those who wish to introduce games in education effectively. 


\section{References}

Ara, S. (2009, February). Use of Songs, Rhymes and Games in Teaching English to Young Learners in Bangladesh. The Dhaka University Journal of Linguistics, 2(3), 161-172.

Atake, K. (2003). Using Games to Teach English in Japanese Junior High School. The Internet TESL Journal .

Chan, D. Y.-c., \& Wu, G.-c. (2004, September). A study of Foreign Language Anxiety of EFL Elementary School Students in Taipei Country. Journal of National Taipei Teachers College, 17(2), 287-320.

Deesri, A. (2002, September). Games in the ESL and EFL Class. The Internet TESL Journal, VIII(9).

Greenall, S. (1984). Language Games and Activities. Great Britain: Hulton Educational Publication.

Gulin Yolagelidi \& Arda Arikan. (2011). Effectiveness of Using Games in Teaching Grammar to Young Leraners. Elementary Education Online, 10(1), 219-229.

Hadfield, J. (1987). Elementary Communication Games. UK: Thomas Nelson and Sons.

Khine, M. S. (2011). Playful Teaching. Learning Games: New Tool for Digital Classrooms.

Larsen-Freeman, D. (2001, February). Techniques and Principles in Language Teaching. Journal of English Studies, 3, 277-281.

Palanova, K. (2010). Use of Games in English Language Teaching.

Prodromou, L. (1992). What culture? Which culture? Cross-cultural factors in languge learning. ELT Journal.

Richarchs, J. C., Platt, J., \& Platt, \&. H. (1995). Longman Dictionary of Language Teaching \& Applied Linguistics. Beijing: Foreign Language Teaching and Research Press.

Richards, J. C., \& Rodgers, T. S. (2001). Approaches and Models in Language Teaching. Cambrigde University Press.

Ruben, R. D. (1999). Simulations, games, and experience-based learning: the quest for a new paradigm for teaching and learning. Sage Journals, 30(4), 498-505.

Slawek. (2007, June 19). The Use of Games and Songs in Teaching English. Retrieved from www.shvoong.com:http://www.shvoong.com/books/guidance-selfimprovement/1620174-games-songs-teaching-english/\#ixzz2KDdX5AtK

Sophie loannou-Georgiou. (2010). Teaching English to very young learners: Using games. Retrieved from www.pi.ac.cy: www. pi.ac.cy/pi/files/.../games.pdf

Uberman, A. (1998, January-March). The use of games: for vocabulary presentation and revision. English Teaching Forum, 36(1), 20.

Wang, Ying-Jian; Briody, Hui-Fang Shang \& Paul. (2011). Investigating the Impact of Using Games in Teaching Children English. International Journal of Learning and Development, $1(1)$.

Ying-Jian Wang, Hui-Fang Shang, \& Paul Briody. (2011). Investigating the Impact of Using Games in Teaching Children English. International Journal of Learning \& Development, l(1).

Yolagelidi, G., \& Arikan, A. (2011). Effectiveness of Using Games in Teaching Grammar to Young Learners. Elementary Education Online, 10(1), 219-229. 